KEMAS 13 (3) (2018) 297-303
Jurnal Kesehatan Masyarakat

\title{
THE COMBINATION OF PROBIOTIC AND CALCIUM CARBONATE DECREASE MONOCYTE COUNT OF END-STAGE RENAL DISEASE PATIENT
}

\author{
Ari Yulistianingsih ${ }^{1 凶}$, Taufik Maryusman ${ }^{2}$, Mohammad Sulchan $^{1}$, Shofa Chasani ${ }^{3}$ \\ ${ }^{1}$ Departemen Ilmu Gizi, Fakultas Kedokteran, Universitas Diponegoro, Indonesia \\ ${ }^{2}$ Program Studi S1 Ilmu Gizi UPN “Veteran” Jakarta, Indonesia \\ ${ }^{3}$ Bagian Penyakit Dalam, Fakultas Kedokteran, Universitas Diponegoro, Indonesia
}

\section{Article Info \\ Article History: \\ Submitted August 2017 \\ Accepted September 2017 \\ Published March 2018 \\ Keywords: \\ probiotic, calcium carbon- \\ ate, monocyte count, \\ end-stage renal disease \\ DOI \\ https://doi.org/10.15294/ \\ kemas.v13i3.10732}

\begin{abstract}
Elevated monocyte count is correlated to the decrease of renal function and disease progressivity on end-stage renal disease (ESRD) patients. Probiotic that utilize lactobacillus species is known to play a role in maintaining imunity system balance by inducing the monocyte apoptosis. The combination between probiotic and calcium carbonate could increase probiotic colonization in the gatrointestinal tract. The aim of this study was to analyze the effect of probiotic and calcium carbonate combination toward reduction of monocyte count on ESRD patient at Rumah Sehat Terpadu Dompet Dhuafa Bogor Hospital. This study was true experimental research with randomized pre-post test control group design. Twenty four ESRD patient were randomly enrolled into treatment group $(n=12)$ and control $(n=12)$. The treatment group received probiotic and calcium carbonate, whereas control group received standardized calcium carbonate for 21 days. There was a significant decrease of monocyte $(\mathrm{p}=0.03)$ after administration of probiotic and calcium carbonate.
\end{abstract}

\section{Introductions}

End-stage renal disease (ESRD) is defined as structural or functional abnormality of renal function with reduced glomerular filtration rate, presence of albuminuria, or both of those occuring for $\geq 3$ months (Inker, 2014). Endstage renal disease is a risk factor for cardiac disease and other systemic complications. The main causes of ESRD in developing countries are diabetes mellitus and hypertension. Global Burden of Disease put ESRD at the 27th rank as world's highest mortality cause at 1990 and raised into 18th rank at 2010 (Jha, 2013). The percentage of ESRD patient undergoing hemodialysis in Indonesia was $84 \%$ on 2014 according to Indonesian Renal Registry report.
The province with highest ESRD cases was West Java province with 3654 number of cases (IRR, 2014).

Renal function damage may influence metabolic balance and glomerular filtration resulting in a condition where the kidney is unable to excrete urea, resulting in urea accumulation in the blood. In general, ESRD patients undergoing hemodialysis are experiencing uremia, hence there would be imbalance between pro- and anti-inflamation and also immune system imbalance. This condition is aggravated by malnutrition which is usually found in ESRD patient (Cohen, 2012). Several studies explained that monocyte count is a predictor of vascular disease and 
atherosclerosis in ESRD patient (Ghattas, 2013). Otherwise, decreasing glomerular filtration rate is related to the increase in monocyte count (Ganda, 2013).

Conservative therapy is one of treatment for ESRD patient. Conservative therapy through medication, nutritional therapy, and precise functional nutrients could improve immune system and nutrient absorption. Probiotic is food supplement originated from living microbes or culture of living microorganism; when given in adequate amount it could maintain gut mcroflora balance and boost immune system. Lactobacillus probiotics are lactic acid bacteria that are commonly used in food industry because they have medicative and therapeutic potency. Systemic inflamation and urea accumulation (uremia) play a role in the pathogenesis of cardiac and vascular disease among ESRD patients caused by gut flora disorder. Lactobacillus is expected to increase nutrient absorption, decrease gastrointestinal tract disorder, and increase immune response (Mafra, 2014). The first probiotic product patented to maintain renal health is capsule probiotic (Renadyl ${ }^{\mathrm{TM}}$ ) consisted of $S$. thermophilus KB 19, L. acidophilus KB 27, dan $B$. longum $\mathrm{KB} 31$ strains, containing 3 billion $\mathrm{CFU}$ per capsule. This probiotic could decrease uremia toxin accumulation in the blood of ESRD patient (Ranganathan, 2013). Studies on probiotic supplement from Lactobacillus casei Shirota strain showed that there was a reduction of leukocyte and improvement in renal function as shown through increased GFR on gastroenteritis patients with acute kidney injury (Akoglu, 2015).

Recently, most probiotic products are packaged in capsule form in order to be easily consumed. Studies on the 3rd and 4th stage of chronic kidney disease revealed that probiotic supplementation in form of capsule (Renadyl ${ }^{\mathrm{TM}}$ ) for 4 months with the highest dosage of $270 \times 10^{9} \mathrm{CFU}$ per day is safe and well tolerated (Ranganathan, 2013). This study utilized probiotic supplementation in the form of Lacidofil ${ }^{\mathrm{TM}}$ capsule consisting of Lactobacillus helveticus Rossell -52 and Lactobacillus rhamnosus Rosell -11 strains with total bacteria of $2.0 \times 10^{9} \mathrm{CFU}$ given as 2 capsules per day, which is a safe from and within safety tolerance limit. Lactobacillus rhamnosus GG could prevent apoptosis induced by cytokines on gut epithelial cell by blocking tumor necrosis factor (TNF) (K Gogineni, 2013). The utilization of probiotic and calcium carbonate combination is known to increase the number viable cell in gastrointestinal tract (Zhao, 2009).

Studies aiming to understand the effect of probiotic strain Lactobacillus toward monocyte count in ESRD patient has not been reported yet. Therefore, the authors were interested to analyze the effect of probiotic and calcium carbonate combination on changes in monocyte count among ESRD patients at Rumah Sehat Terpadu Dompet Dhuafa Bogor Hospital.

\section{Methods}

This study was true experimental study with randomized pre-post test control group design conducted in Hemodialysis Unit Rumah Sehat Terpadu Dompet Dhuafa Hospital, Bogor, West Java, Indonesia on February - March, 2017. Subjects were randomly divided into two groups consisting of treatment group and control group. Subject inclusion criteria were 1) ESRD patient undergoing hemodialysis for $>3$ months, 2) male or female aged $18-60$ years old, 3) having good nutritional status measured by anthropometry. Exclusion criteria were 1) HIV/AIDS patient, 2) patients consuming immunosuppressant and immunomodulator medications, 3) patient with high fever. Drop out criteria were died or admitted into Intensive Care Unit (ICU).

The sample size was determined by minimal sample measurement formula. To prevent drop out possibility of sample, the researchers added reserve samples as much as $20 \%$. Sample size needed for each groups were 13 subjects, therefore the total sample size needed were $2 \times 13$ subjects $=26$ subjects. Treatment group received intervention in form of combined probiotic at a dosage of $2 \times 10^{9} \mathrm{CFU}$, 2 capsules per day, and calcium carbonate 500 $\mathrm{mg} \times 3$ tablets per day for 21 days. Control group only received standardized intervention which was calcium carbonate $500 \mathrm{mg}$ x 3 tablets per day for 21 days. Intervention was monitored by intake compliance form.

Lacidofil ${ }^{\mathrm{TM}}$ capsule containing

Lactobacillus helveticus Rossell-52 $0.1 \times 10^{9}$ 
CFU and Lactobacillus rhamnosus Rosell-11 1.9 x $10^{9} \mathrm{CFU}$ with total bacteria count $2.0 \times 10^{9}$ CFU was used as the probiotic in this study. Product safety for Lacidofil ${ }^{\mathrm{TM}}$ in Indonesia is in accordance to FAO/WHO 2002 standard, which is containing living bacteria in order to maintain gut flora balance, having adequate amount (containing 2 billion bacteria), and being registered at North America and Europe based on clinical research. Monocyte count was conducted before and after intervention by laboratorium staff using flow cytometry method and hematology analyzer tools. Nutritional intake data was obtained through 24 hours food recall method. Data results of nutritional intake were determined using Nutrisurvey 2007 program and compared with Nutritional Adequacy Rate (NAR) 2013. Statistical analysis was based on independent t-test and paired t-test. Subjects received written inform consent before being enrolled to study. This study had obtained Ethical Clearance agreement from Health Research Ethics Committee, Faculty of Medicine, Universitas Diponegoro Semarang (No.149/EC/FK-RSDK/IV/2017).

\section{Results and Discussions}

Number of research subjects fulfilling inclusion and exclusion criteria was 26 subjects and were divided into control and treatment group with simple randomization method. During the research, there were 2 drop outs, leaving 24 remaining subjects. Subjects' characteristic (Table 1) showed that treatment group was mostly male, whereas control group was mostly female. Dialysis Outcomes and Practice Patterns Study (DOPPS) prospective study mentioned that hemodialysis patient was mostly male because average GFR value of male patients was higher than female (Bohlke, 2008). However, US Renal Data System (USRDS) reported that Chronic Kidney Disease prevalence in 2007-2012 was higher among females $(15.1 \%)$ than males (12.1\%) (USRDS, 2016).

Chronic Kidney Disease (CKD) is a multifactorial disease affected by many risk factors including hypertension, type II DM, heart disease, and asthma. According to past illness, several subjects in the treatment group had a history of hypertension $(\mathrm{N}=10 ; 83.3 \%)$, meanwhile in the control group some had type II DM $(n=5 ; 41.7 \%)$ and hypertension $(n=5$; 41.7\%). Indonesian Renal Registry reports on 2014, the main cause of CKD is hypertension, as many as 37\% (IRR, 2004). Cross sectional research on 2011 by Eva at Bogor concluded that subjects with hypertension and type II DM had higher risk, 3.7 times and 2.5 times

Table 1. Subject Characteristics Description

\begin{tabular}{lllll}
\hline \multirow{2}{*}{ Characteristics } & \multicolumn{2}{l}{$\begin{array}{l}\text { Treatment Group } \\
(\mathrm{n}=12)\end{array}$} & $\begin{array}{l}\text { Control Group } \\
(\mathrm{n}=12)\end{array}$ \\
\cline { 2 - 5 } $\mathrm{n}$ & 7 & $\mathrm{n}$ & $\%$ \\
\hline Gender & 5 & 58.3 & 5 & 41.7 \\
Male & & 41.7 & 7 & 58.3 \\
Female & 1 & 8.3 & 5 & 41.7 \\
\hline Disease History & 10 & 83.3 & 5 & 41.7 \\
Diabetes & 0 & 0 & 1 & 8.3 \\
Hypertension & 1 & 8.3 & 1 & 8.3 \\
Cardiac disease & & & & \\
Asthma & 1 & 8.3 & 1 & 8.3 \\
\hline Nutritional Status & 6 & 50 & 7 & 58.3 \\
Under & 5 & 41.7 & 4 & 33.3 \\
Normal & & & & \\
Over & 8 & 66.7 & 9 & 75 \\
\hline Duration of Hemodialysis (months) & 1 & 8.3 & 2 & 16.7 \\
$4-12$ & 1 & 8.3 & 1 & 8.3 \\
$13-24$ & 2 & 16.7 & 0 & 0 \\
$25-36$ & & & & \\
$37-48$ & & & & \\
\hline
\end{tabular}

Source : Primary Data 
Ari Yulistianingsih, et al / The Combination of Probiotic and Calcium Carbonate Decrease Monocyte

Table 2. Subject Characters in the Beginning of the Research

\begin{tabular}{llllllllll}
\hline \multirow{2}{*}{ Character } & \multicolumn{7}{l}{ Treatment group $(\mathrm{n}=12)$} & \multicolumn{7}{c}{ Control group $(\mathrm{n}=12)$} & \\
\cline { 2 - 9 } & Med & Min & Max & Mean \pm SD & Med & Min & Max & Mean \pm SD & \\
\hline $\begin{array}{l}\text { Age (year) } \\
\begin{array}{l}\text { Monocyte } \\
\text { count (\%) }\end{array}\end{array}$ & 44.5 & 24 & 63 & $44.2 \pm 11.5$ & 52 & 33 & 60 & $48.7 \pm 9.7$ & $0.31^{\mathrm{a}}$ \\
\hline
\end{tabular}

${ }^{\mathrm{a} I n d e p e n d e n t ~ t-t e s t ~}$

Table 3. Nutrition Intake and Consumption Level

\begin{tabular}{llll}
\hline Variable & Treatment Group $(\mathrm{n}=12)$ & Control Group $(\mathrm{n}=12)$ & $p$ \\
\hline Nutrition Intake & & & \\
Vitamin C (mg) & $40.68 \pm 26.4$ & $21.2(3-145.1)$ & $0.2^{\mathrm{b}}$ \\
Vitamin A ( $\mu \mathrm{g})$ & $827.9(33.4-4746.5)$ & $652.5(130.3-3445.7)$ & $0.53^{\mathrm{b}}$ \\
Zinc $(\mathrm{mg})$ & $4.54 \pm 1.6$ & $3.68 \pm 1.1$ & $0.13^{\mathrm{a}}$ \\
Consumption Level (\%) & & & \\
Vitamin C & $49.3 \pm 34.1$ & $28.2(4-193.5)$ & $0.25^{\mathrm{b}}$ \\
Vitamin A & $156.4(5.6-949.3)$ & $127.3(21.7-689.1)$ & $0.53^{\mathrm{b}}$ \\
Zinc & $39.8 \pm 16.2$ & $32.8 \pm 8.9$ & $0.2^{\mathrm{a}}$ \\
\hline a : Independent t test & $\mathrm{b}:$ Mann-Whitney & &
\end{tabular}

respectively, for developing CKD (Sulistiowati, 2015).

Most subjects in the treatment $(\mathrm{n}=8$; $66.7 \%)$ and control $(n=9 ; 75 \%)$ group had been on hemodialysis therapy less than 13 months. Of $6(50 \%)$ subjects in the treatment group and $7(58.3 \%)$ subjects of control group had normal nutrition index. Chi-yuan research mentioned that $58 \%$ people with CKD had normal body mass index (BMI). A high BMI is a risk factor for developing CKD (Hsu, 2006), whereas other studies defined that BMI $>40 \mathrm{~kg} / \mathrm{m}^{2}$ was not related to mortality caused by heart disease and non-malignancy in CKD patients. The duration of hemodialysis affects the health and life quality of CKD patients. A research stated that there was significant difference between quality of life and psychological and physical dimension in CKD patients after being treated with hemodialysis (Supriyadi, 2013).

The mean age was 44.2 years old (treatment group) and 48.7 years old (control group) with the youngest and oldest age was 24 years old and 63 years old, respectively. In 2010, globally, almost end stage renal disease developed in patients aged more than 65 years old (USRDS, 2016). Therefore, in this research CKD can be developed in 24 years old patient. The normal monocyte count based on references was 2-8\%. Mean monocyte count was in the normal range in both group $(8.8 \pm 3.7 \% \mathrm{n}$ treatment group with the highest value being $17 \%$, meanwhile in control group it was $7.4 \pm 2 \%$ with the highest value being $10 \%$ ). There was no statistical difference in mean age and monocyte count between two groups at the beginning of the research $(\mathrm{p}>0.05)$ (Table 2).

Mean intake of vitamin C (40.68), vitamin A (1251.6 mg), and zinc (4.54mg) was higher in treatment group than control group with consecutive mean $31.65 \mathrm{mg}, 1215.6 \mu \mathrm{g}$, and $3.68 \mathrm{mg}$ but there was no statistically significant difference in intake between the two groups $(\mathrm{p}>0.05)$. Mean consumption level of vitamin C (49.3\%), vitamin A (236.8\%), and zinc (39.8\%) was higher in treatment group than control group with consecutive percentages $40.1 \%$, $222.9 \%, 32.8 \%$. Therefore, mean consumption level of vitamin $\mathrm{c}$ and zinc in both groups were in deficit category $(<70 \%)$, in contrast with vitamin A consumption level which was in high category $(>100 \%)$.

CKD patients have decreased vitamin and mineral intake due to malnutrition and gastrointestinal disorder. Current research is concordance with other studies in which vitamin C intake in CKD patients were low due to potassium restriction. Oxalates, metabolite of ascorbic acid, in urine and serum were elevated in CKD patients who received ascorbic 
Table 4. The Effect of Probiotic and Calcium Carbonate Combination on Monocyte Count.

\begin{tabular}{llll}
\hline Variable & Treatment Group & Control Group & $\mathrm{p}$ \\
\cline { 2 - 3 } & $(\mathrm{mean} \pm \mathrm{SD})$ & $($ mean \pm SD) & \\
\hline Monocyte count & & & \\
Before treatment & $8.8 \pm 3.7$ & $7.4 \pm 2.0$ & $0.28^{\mathrm{b}}$ \\
After 21 days & $7.2 \pm 3.1$ & $8.6 \pm 2.5$ & $0.23^{\mathrm{b}}$ \\
$\Delta$ monocyte count $(\%)$ & $-1.6 \pm 2.2$ & $1.2 \pm 2.5$ & $0.01^{\mathrm{b}}$ \\
$\mathrm{p}$ & $\mathrm{p}=0.03^{\mathrm{a}}$ & $\mathrm{p}=0.13^{\mathrm{a}}$ & \\
\hline${ }^{\mathrm{a}}$ paired t-test bindependent t-test & & &
\end{tabular}

supplementation. High dose of vitamin $\mathrm{C}$ was not recommended for CKD patients since it increased risk for hyperoxalosis. Furthermore, recent study investigated that consumption of $500 \mathrm{mg}$ vitamin $\mathrm{C}$ daily in non-CKD patients at risk of oxalate stone formation did not increase oxalate excretion in urine (Steiber, 2011). Vitamin A consumption was high in both groups, which was consistent with the theory that CKD patients had higher level of vitamin $\mathrm{A}$ in serum. The responsible mechanisms are decreased RBP (retinol binding protein) catabolism as main transporter, or elevation blood retinol in CKD patients. It means that vitamin A supplementation is not needed for CKD patients.

Ho was accepted according to statistical analysis $\mathrm{p}<0.05$, in which there was no difference between Vitamin $C$, vitamin $A$, and Zinc intake in both group $(\mathrm{p}<0.05)$. Most of the subjects consume rice-vegetables only, riceegg white, or rice-tempeh only in every meal. Moreover, CKD patients had lower food intake due to gastrointestinal disorder including deceased appetite, nausea, and vomiting due to haemodialysis (Yani, 2017).

Table 4 shows the influence of probiotic and calcium carbonate combination on monocyte count. Monocyte count decreased $1.6 \%$ in treatment group and increased $1.2 \%$ in control group. There was significant difference in monocyte count between the two groups after intervention $(p=0.01)$, as well as the difference in monocyte count before and after administration of probiotic and calcium carbonate combination $(p=0.03)$.

Non-specific immune response, including mononuclear cell (monocyte and macrophage) and polymorphonuclear cell, plays a role as the first defence. Monocyte act as antigen presenting cells for microbes, tissue regeneration process, pathogenesis of inflammation, and atherosclerosis. Monocyte count in control group was significantly decreased $(p=0.03)$ and this was in accordance to the study by Gleeson et al, which found that probiotic (Lactobacillus casei Shirota) administration to infected athletes could reduce monocyte count (Gleeson, 2011). In contrast, other studies found that probiotic administration for 4 weeks did not affect phagocytosis activity and cytokine secretion of mononuclear cells (Seifert, 2011). The differences in outcome might be caused by different probiotic dose, duration of intervention and food intake. After the intervention, the average number of monocyte in control group tend to elevate. This could be due to Diabetes mellitus which was found more in control group than treatment group. The responsible mechanism for monocyte count increase in DM patients was not fully understood. Total peripheral leucocyte, monocyte, and neutrophil were elevated in line with diabetic nephropathy. Nephropathy diabetic patients was significantly related to total leucocyte count.

Mucosal immune system protects mucous membrane from pathogenic microbe invasion, protect antigen uptake, and prevent abnormal immune response. Mucosal-associated lymphoid tissue (MALT) is aggregation of nonencapsulated organized lymphoid tissue that is populated by $\mathrm{T}$ cells, $\mathrm{B}$ cells, and APC (antigen-presenting cells) or dendritic cells. MALT play an important role in selecting mechanism and intensity of an effector to avoid tissue damage and excessive immune response, especially in regulating the balance between pro- and anti- inflammatory cytokine (Kataoka, 2013).

Some In-vitro studies investigated that L. helveticus met the criteria for probiotic since 
its characteristics includes the capability to defend against pathogenic bacteria, survive in gastrointestinal tract, and its existence in epithelial cells. Moreover, in vivo study in animals showed that $L$. helveticus could stimulate immune system, improve defence against pathogenic bacterial, influence gastrointestinal tract (GIT) microbiota population, and prevent GIT infection. Protective effect was found when L. helveticus was taken orally (Skrzypczak, 2015). Lactobacillus rhamnosus Rosell-11 has benefits for GIT and immune system, especially defending against pathogens in GIT and urinary tract. Lactobacillus rhamnosus prevent pathogenic bacteria growth in GIT. Goldin dan Gorbach investigated that L. rhamnosus was resistant to stomach acid. A study on patients with renal disease elucidate that L. rhamnosus could be transported through GIT resistant to vancomycin antibiotic (Manley, 2007).

Lactobacillus rhamnosus $G G$ act on monocyte and macrophage by increasing INF囚, IL-12, and IL-18 production and NF$\kappa \mathrm{B}$ induction (Kusumaningsih, 2014). Ex vivo research stated that mononuclear and polymorphonuclear phagocytic activity increased following L. rhamnosus HN001 and B. lactis HN109 consumption. The known mechanism was that Lactobacillus rhamnosus and Lactobacillus helveticus produce inhibitor substances (lactic acid and bacteriomycin) for epithelial cells adhesion (Delcenserie, 2008). This process helps the normal flora to dominate, stimulate mucus production, metabolic activity that reduce microbe toxin, help food digestion, and balance the inflammatory cytokine and interleukin.

Calcium carbonate is the standard intervention for end-stage renal disease. KDOQI (Kidney Disease Outcomes Qualitative Initiative) suggested that calcium carbonate administration for CKD patients on hemodialysis was aimed to manage calcium and phosphor concentration as well as bone calcification. The combination of calcium carbonate with lactic acid strain probiotic is expected to increase calcium carbonate absorption since it needs acidic condition to dissolve well in small intestine (Houtkooper, 2017). Furthermore, administration of probiotic containing Lactobacillus strain can increase viable cell up to $150-220 \%$ (Zhao, 2009). However, other studies suggested that addition of calcium phospate in Lactobacillus helveticus R002 and Lactobacillus rhamnosus R0011 probiotic supplementation could increase the number of Lactobacillus spp viable cell, while calcium carbonate could not (Dahl, 2016).

\section{Conclusion}

There was a significant decrease in monocyte count in the treatment group $(p=0.03)$. Monocyte count decreased by $1.6 \%$ in treatment group and increased by $1.2 \%$ in control group. There was significant difference in monocyte count between the two groups after intervention $(p=0.01)$. The limitations of this study are uninvestigated components of the drugs that could influence subject's appetite and nutrition absorption, no investigation on subjects' microflora status that could influence probiotic absorption, and each subject's diagnosis was not mentioned. Our suggestion was an addition of probiotic supplementation for CKD patients which could reduce monocyte count.

\section{Reference}

Akoglu, B., et al. 2015. Probiotic Lactobacillus casei Shirota Improves Kidney Function, Inflammation and Bowel Movements in Hospitalized Patients with Acute Gastroenteritis - A Prospective Study. Journal of Functional Foods, 17: 305-313.

Bohlke, M., et al. 2008. Predictors of Quality of Life among Patients on Dialysis in Southern Brazil. São Paulo Medical Journal Revista Paulista de Medicina, 126 (5): 252-6.

Cohen, G., and Hörl, W. H. 2012. Immune dysfunction in Uremia-An update. Toxins, 4 (11): 962-990.

Dahl, W. J., et al. 2016. Calcium Phosphate Supplementation Increases Faecal Lactobacillus spp. in a randomised trial of young adults. Beneficial Microbes, 7 (1):3-10.

Delcenserie, V., et al. 2008. Immunomodulatory Effects of Probiotics in the Intestinal Tract. Curr Issues Mol Biol, 10 (1-2): 37-54.

Ganda, A., et al. 2013. Mild Renal Dysfunction and Metabolites Tied to Low HDL Cholesterol are Associated with Monocytosis and Atherosclerosis. Circulation, 127 (9): 988996.

Ghattas, A., et al. 2013. Monocytes in Coronary Artery Disease and Atherosclerosis: Where 
are We Now? Journal of the American College of Cardiology, 62 (17): 1541-1551.

Gleeson, M., Bishop, N. C., Oliveira, M., and Tauler, P. 2011. Daily probiotic's (Lactobacillus casei Shirota) Reduction of Infection Incidence in Athletes. International Journal of Sport Nutrition and Exercise Metabolism, 21 (1): 55-64.

Houtkooper, L., Farrell, V., and Mullins, V. 2017. Calcium Supplement Guidelines. College of Agriculture and Life Sciences, 1-4.

Hsu, C., et al. 2006. Body Mass Index and Risk for End-Stage Renal Disease. Annals of Internal Medicine, 144 (1): 21-8.

Inker, L. A.,, et al. 2014. KDOQI US Commentary on the 2012 KDIGO Clinical Practice Guideline for the Evaluation and Management of CKD. American Journal of Kidney Diseases, 63 (5): 713-735.

IRR. 2014. Report of Indonesian Renal Registry 2014.

Jha, V.,, et al. 2013. Chronic Kidney Disease: Global Dimension and Perspectives. The Lancet, 382 (9888): 260-272.

K Gogineni, V., and Morrow, L. E. 2013. Probiotics: Mechanisms of Action and Clinical Applications. Journal of Probiotics \& Health, 1 (1): $1-11$.

Kataoka, Y., et al. 2013. Synbiotics Reduce Infectious Complications by Improving the Intestinal Milieu and Enhancing the Immune Function in Critically Ill Emergency Surgical Patients. Kitasato Med J, 43: 17-25.

Kusumaningsih, T. 2014. Peran Bakteri Probiotik terhadap Innate Immune Cell (The Role of Probiotic Bacteria on Innate Immune Cells). Oral Biology Journal, 6 (2): 45-50.

Mafra, D., et al. 2014. Role of Altered Intestinal Microbiota in Systemic Inflammation and Cardiovascular Disease in Chronic Kidney Disease. Future Microbiology, 9 (3): 399-410.

Manley, K. J., et al. 2007. Probiotic Treatment of Vancomycin-Resistant Enterococci: A Randomised Controlled Trial. Medical Journal of Australia, 186 (9): 454-457.
Ranganathan, N., et al. 2013. Nephrology \& Therapeutics Dose Escalation, Safety and Impact of a Strain-Specific Probiotic (Renadyl ${ }^{\mathrm{TM}}$ ) on Stages III and IV Chronic Kidney Disease Patients. Nephrology and Therapeutics, 3 (3): 1-9.

Seifert, S., Bub, A., Franz, C. M. A. P., and Watzl, B. 2011. Probiotic Lactobacillus casei Shirota Supplementation Does Not Modulate Immunity in Healthy Men with Reduced Natural Killer Cell Activity. The Journal of Nutrition, 141 (5): 978-984.

Skrzypczak, K., Gustaw, W., and Waśko, A. 2015. Health-Promoting Properties Exhibited by Lactobacillus Helveticus Strains. Acta Biochimica Polonica, 62 (4): 713-720.

Steiber, A. L., and Kopple, J. D. 2011. Vitamin Status and Needs for People with Stages 3-5 Chronic Kidney Disease. Journal of Renal Nutrition, 21 (5): 355-368.

Sulistiowati, Eva. Idaiani, Sri. 2015. Faktor Risiko Penyakit Ginjal Kronik Berdasarkan Analisis Cross-sectional Data Awal Studi Kohort Penyakit Tidak Menular Penduduk Usia 25-65 Tahun di Kelurahan Kebon Kalapa, Kota Bogor Tahun 2011. Buletin Penelitian Kesehatan, 43 (3): 163-172.

Supriyadi, Wagiyo, dan Ratih Widowati, S. 2013. Tingkat Kualitas Hidup Pasien Gagal Ginjal Kronik Terapi Hemodialisis. Jurnal Kesehatan Masyarakat, 8 (2): 113-120.

USRDS. 2016. 2015 USRDS Annual Data Report Volume 2: Epidemiology of Kidney Disease in the United States. United States Renal Data System, 2: 1-274.

Yani, A., Nugraha, G. I., and Marhaeni, D. 2017. Analysis of Nutrition Care Chronic Renal Failure Patients with Health Technology Assessment. Jurnal Kesehatan Masyarakat, 13 (272): 96-105.

Zhao, X., Zhang, Y., and Li, D. 2009. Elimination of Acidic or Oxidative Stress for Four Probiotics with Some Chemicals in Vitro. African Journal of Microbiology Research, 3 (7): 353357. 